\title{
Host National Identification of Immigrants in the Netherlands
}

\author{
De Vroome, T., Verkuyten, M., Martinovic, B. \\ International Migration Review
}

\begin{abstract}
This study examines immigrants' identification with the host country. We use survey data of more than 1700 Turkish and Moroccan immigrants and more than 2200 natives in the Netherlands. We answer four main questions in this study. First, do immigrants have lower national identification than natives? Second, does the level of national identification differ between immigrant groups? Third, do economic and social integration similarly affect national identification among immigrants and natives? And fourth, what are important additional determinants of national identification among immigrants? The results show that, compared to Dutch natives, Turkish but not Moroccan immigrants have lower national identification. Being employed and socially integrated is associated with higher national identification among immigrants as well as natives, but only among immigrants is higher occupational status associated with higher national identification. For immigrants, Dutch language proficiency, perceived discrimination, and contact with natives proved to be important conditions for national identification.
\end{abstract}

Key words: national identification, immigrants, natives, the Netherlands

The full article is available online:

De Vroome, T., Verkuyten, M., Martinovic, B. (2014).

Host National Identification of Immigrants in the Netherlands.

International Migration Review, 48(1), 76-102.

http://dx.doi.org/10.1111/imre.12063 